\title{
Pertumbuhan Tanaman Kakao (Theobroma cacao L.) Belum Menghasilkan pada Pemberian Pupuk NPK Phonska
}

\section{Growth of Immature Cocoa Plants (Theobroma cacao L.) in The Provision of NPK Phonska Fertilizers}

\author{
Purwati \\ Tenaga Pendidik Program Studi Agroteknologi, Fakultas Pertanian, Universitas Widya Gama Mahakam \\ Jl. KH. Wahid Hasyim, Sempaja, Samarinda, Kalimantan Timur, Indonesia
}

Email : purwati@uwgm.ac.id

Diterima : 4 April 2019 Disetujui : 17 Juni 2019

\begin{abstract}
The aim of the study was to determine the growth of immature cocoa plants in the provision of NPK phonka fertilizer. This research was conducted from February to May 2016 in North Samarinda District, East Kalimantan. The study used a randomized block design with five replications. The treatment of NPK Phonska fertilizer (N) consists of 3 levels, namely control (n0), $250 \mathrm{~g} /$ plant (n1), $500 \mathrm{~g} /$ plant ( $\mathrm{n} 2)$. Data were analyzed statistically and tested further with the smallest significant difference test (LSD) at the level of 5\%. The results showed that the best growth of cocoa plants was the administration of Phonska NPK $500 \mathrm{~g} /$ plant.
\end{abstract}

Keywords: Cocoa plant, NPK phonska fertilizer

\section{PENDAHULUAN}

Kakao merupakan salah satu komoditas andalan perkebunan yang peranannya cukup penting bagi perekonomian nasional, khususnya sebagai penyedia lapangan kerja, sumber pendapatan dan devisa Negara serta berperan dalam mendorong pengembangan wilayah dan pengembangan agroindustri. Disamping itu pemerintah pusat telah mencanangkan program Gerakan Peningkatan Produksi dan Mutu Kakao Nasional (Gernas) yang menjadi salah satu program unggulan Kementerian Pertanian, khususnya Direktorat Jenderal Perkebunan (Disbun Kaltim 2009).

Komoditas kakao memberikan kontribusi yang cukup besar terhadap penerimaan devisa negara setelah kelapa sawit, karet, kelapa dan kopi, meskipun produksi dan harga kakao di pasar dunia selalu berfluktuasi (Herman, 2000).

Daerah penghasil kakao Indonesia adalah sebagai berikut: Sulawesi Selatan 184.000 ton $(28,26 \%)$, Sulawesi Tengah 137.000 ton $(21,04 \%)$, Sulawesi Tenggara 111.000 ton $(17,05 \%)$, Sumatera Utara 51.000 ton $(7,85 \%)$, Kalimantan Timur 25.000 ton $(3,84 \%)$, Lampung 21.000 ton $(3,23 \%)$ dan daerah lainnya 122.000 ton $(18,74 \%)$ (Teja Primawati Utami, 2014).

Luas lahan tanaman kakao menurut statistik tahun 2013 sebesar 22.455 ha dengan produksi biji kakao kering sejumlah 9.527 ton (Disbun Kaltim, 2013).
Upaya untuk meningkatkan produktivitas dan produksi kakao perlu dilakukan pemupukan. Pemupukan merupakan kegiatan pemeliharaan tanaman yang bertujuan untuk memperbaiki kesuburan tanah berupa penambahan unsur hara makro dan mikro untuk pertumbuhan dan perkembangan tanaman kakao. Dalam mencapai produktivitas yang tinggi maka pemupukan merupakan faktor penentu utama pada keseimbangan dosis dan jenis pupuk yang digunakan.

Unsur-unsur hara yang perlu ditambahkan pada pemupukan tanaman kakao meliputi nitrogen, fosfor, kalium dan magnesium. Pupuk NPK Phonska merupakan pupuk majemuk yang mengandung unsur hara makro yang diperlukan untuk pertumbuhan tanaman kakao.

\section{BAHAN DAN METODE}

Penelitian dilaksanakan di Kebun Petani di Kecamatan Samarinda Utara Kota Samarinda, Kalimantan Timur dari bulan Februari sampai dengan Mei 2016. Bahan tanam yang digunakan adalah tanaman kakao umur 1 tahun, pupuk NPK Phonska 15:15:15. Alat yang digunakan adalah cangkul, parang, gembor, kamera dan alat tulis menulis. Tanaman kakao diberi label perlakuan dan dibersihkan dari gulma di sekitar tanaman. Pupuk NPK Phonska diberikan pada tanaman kakao sesuai dengan 
masing-masing perlakuan. Pengamatan dilakukan sebelum dan setelah perlakuan. Pengamatan setelah perlakuan dilakukan dua bulan sekali, mulai umur 2 sampai dengan 4 bulan setelah perlakuan (BSP). Parameter yang diamati meliputi: tinggi tanaman, diameter batang, dan panjang cabang primer. Penelitian ini menggunakan Rancangan Acak Kelompok (RAK) dengan lima ulangan. Perlakuan meliputi pupuk NPK Phonska $(\mathrm{N})$ yang terdiri dari 3 taraf yaitu kontrol $\left(\mathrm{n}_{0}\right), 250 \mathrm{~g} /$ tanaman $\left(\mathrm{n}_{1}\right), 500 \mathrm{~g} / \operatorname{tanaman}\left(\mathrm{n}_{2}\right)$.

\section{HASIL DAN PEMBAHASAN}

Tabel 1. Rata-rata pertumbuhan tanaman kakao pada pemberian pupuk NPK Phonska

\begin{tabular}{ccccccc}
\hline \multirow{2}{*}{ Perlakuan } & \multicolumn{2}{c}{ Tinggi Tanaman $(\mathrm{cm})$} & \multicolumn{2}{c}{ Diameter Batang $(\mathrm{mm})$} & \multicolumn{2}{c}{ Panjang Cabang Primer $(\mathrm{cm})$} \\
\cline { 2 - 7 } & 2 bulan & 4 bulan & 2 bulan & 4 bulan & 2 bulan & 4 bulan \\
\hline Kontrol $\left(\mathrm{n}_{0}\right)$ & $34,20^{\mathrm{c}}$ & $38,20^{\mathrm{c}}$ & $09,20^{\mathrm{c}}$ & $10,20^{\mathrm{c}}$ & 27,80 & 30,20 \\
$250 \mathrm{~g} / \operatorname{tanaman}\left(\mathrm{n}_{1}\right)$ & $36,00^{\mathrm{b}}$ & $40,00^{\mathrm{b}}$ & $10,60^{\mathrm{b}}$ & $11,60^{\mathrm{b}}$ & 28,60 & 31,00 \\
$500 \mathrm{~g} / \operatorname{tanaman}\left(\mathrm{n}_{2}\right)$ & $37,40^{\mathrm{a}}$ & $41,60^{\mathrm{a}}$ & $12,00^{\mathrm{a}}$ & $13,20^{\mathrm{a}}$ & 29,40 & 31,40 \\
\hline
\end{tabular}

Keterangan: Angka-angka yang diikuti huruf yang sama pada kolom yang sama tidak berbeda nyata menurut uji BNT taraf $5 \%$

Pupuk NPK Phonska berpengaruh terhadap tinggi tanaman dan diameter batang, namun tidak berpengaruh terhadap panjang cabang primer. Rata-rata pertumbuhan tanaman kakao yang ditunjukkan oleh tinggi tanaman, diameter batang dan panjang cabang primer, tercantum pada Tabel 1 .

Berdasarkan Tabel 1 tampak bahwa pemberian pupuk NPK Phonska 500 $\mathrm{g} /$ tanaman menunjukkan pertumbuhan tinggi tanaman, diameter batang dan panjang cabang primer yang terbaik dibandingkan dengan pemberian pupuk NPK Phonska 250 g/tanaman dan kontrol.

\section{Tinggi Tanaman}

Perlakuan pupuk NPK Phonska berpengaruh terhadap tinggi tanaman umur 2 dan 4 bulan setelah perlakuan (BSP). Pupuk NPK Phonska 500 g/tanaman yang diaplikasikan memiliki tinggi tanaman lebih tinggi yaitu sebesar $37,40 \mathrm{~cm}$ dan $41,60 \mathrm{~cm}$ (Tabel 1). Hal ini diduga pemberian pupuk NPK phonska 500 g/tanaman dapat meningkatkan ketersediaan unsur hara dan dimanfaatkan oleh tanaman untuk mendukung pertumbuhannya. Sehingga bila proses fisiologis yang terjadi pada tanaman berjalan dengan baik dan didukung dengan penerapan pemupukan yang efisien mampu meningkatkan tinggi tanaman. sehingga untuk mendapatkan pertumbuhan tanaman yang optimal, membutuhkan pemberian pupuk dengan dosis dan cara pemberian yang tepat. Dijelaskan oleh Salisbury dan Ross (1991) bahwa ketersediaan unsur hara makro dan mikro akan membantu proses fisiologis tanaman berjalan dengan baik.

Nitrogen merupakan penyusun utama protein dan sebagai bagian dari klorofil yang mempunyai peranan penting pada proses fotosintesis (Tisdale dkk., 2003). Fotosintat yang dihasilkan dalam fotosintesis dapat digunakan tanaman untuk proses pembelahan sel tanaman, sehingga tanaman kakao mengalami pertambahan tinggi. $\mathrm{N}$ juga berfungsi untuk merangsang pertumbuhan secara keseluruhan, khususnya batang, cabang dan daun, dibutuhkan dalam jumlah yang besar terutama saat pertumbuhan vegetatif. Kebutuhan hara tanaman yang terpenuhi akan menyebabkan laju pembelahan, pemanjangan sel serta pembentukan jaringan berjalan cepat sehingga bobot segar dan bobot kering tanaman juga meningkat. Lebih lanjut dijelaskan Gardner dkk (1991) bahwa peningkatan jumlah sel dan lebar sel akan menyebabkan pertumbuhan tinggi tanaman juga meningkat.

Selain itu pemberian pupuk NPK Phonska dapat menghasilkan tinggi tanaman yang sesuai dengan standar mutu bibit kakao menurut Departemen Pertanian. Menurut Direktorat Jenderal Perkebunan, Departemen Pertanian (2008), mutu bibit kakao yang baik untuk ditanam di lapangan harus memenuhi mutu dari bibit yang siap ditanam, yaitu umur bibit 3-6 bulan, tinggi minimum $20 \mathrm{~cm}$, jumlah daun minimum 10 helai, warna daun hijau segar, dan diameter batang minimum $5 \mathrm{~mm}$. 


\section{Diameter Batang}

Perlakuan pupuk NPK Phonska berpengaruh terhadap diameter batang umur 2 BSP dan 4 BSP. Pupuk NPK Phonska 500 g/tanaman yang diaplikasikan memiliki diameter batang umur 2 BSP dan 4 BSP lebih besar yaitu sebesar $12,00 \mathrm{~cm}$ dan $37,33 \mathrm{~cm}$ (Tabel 1). Diameter batang dengan rata-rata terbesar dihasilkan pada perlakuan Pupuk NPK Phonska $500 \mathrm{~g} /$ tanaman (Tabel 1). Hal ini diduga ketersediaan unsur hara pada pemberian pupuk $500 \mathrm{~g} / \mathrm{tanaman}$ dapat dimanfaatkan oleh tanaman kakao sehingga dpat meningkatkan diameter batang. Sebagaimana dikemukakan oleh Lingga (2007) bahwa kalium berperan dalam menguatkan vigor tanaman sehingga meningkatkan diameter batang. Peningkatan diameter batang juga dipengaruhi oleh unsur Kalium yang berperan dalam pertumbuhan jaringan meristematik khususnya batang tanaman. Lebih lanjut Tisdale dkk (2003) menyatakan bahwa unsur hara kalium juga berperan sebagai aktivator enzim esensial pada reaksi fotosintesis dan respirasi.

\section{Panjang Cabang Primer}

Perlakuan pupuk NPK Phonska tidak berpengaruh terhadap panjang cabang primer umur 2 BSP dan 4 BSP. Pupuk NPK Phonska tidak berpengaruh terhadap panjang cabang primer. Tidak terdapatnya pengaruh pupuk NPK Phonska terhadap panjang cabang primer disebabkan oleh penyerapan air tanaman cukup tinggi, karena curah hujan selama penelitian berlangsung cukup tinggi dengan rata-rata per bulan 407,14 mm. Selain itu, tidak adanya bulan kering selama penelitian mengakibatkan unsur hara di dalam tanah dapat diserap dengan

\section{DAFTAR PUSTAKA}

Direktorat Jenderal Perkebunan, Departemen Pertanian. 2008. Pedoman Umum Penyediaan Bibit Kakao. Jakarta.

Direktorat Jenderal Perkebunan. 2014. Statistik Perkebunan Indonesia Komoditas Kakao 2013-2015. http://ditjenbun.pertanian.go.id/tinymcpu k/gambar/file/statistik/2015/KAKAO\%2 02013\%20-2015.pdf.

Disbun Kaltim. 2009. Gernas Kakao Mulai Memanas. baik sehingga translokasi unsur hara ke batang dan proses pertumbuhan dan perkembangan tanaman termasuk panjang cabang primer menjadi baik.

Aplikasi pupuk NPK phonska 500 g/tanaman pada penelitian ini menghasilkan pertumbuhan tinggi tanaman, diameter batang dan panjang cabang primer yang terbaik. Secara umum tampak bahwa pertumbuhan kakao dengan dosis pupuk NPK Phonska 500 g/tanaman relatif lebih baik dibandingkan dengan pemberian pupuk NPK Phonska 250 g/tanaman. Hal tersebut menunjukkan bahwa masih perlu peningkatan dosis untuk memperoleh pertumbuhan kakao secara nyata. Wachyar dan Kadarisman (2007) melaporkan bahwa pemberian pupuk buatan melalui tanah memberikan pertumbuhan tanaman kakao TBM yang lebih baik.

\section{KESIMPULAN}

1. Pemberian pupuk NPK Phonska berpengaruh terhadap tinggi tanaman dan diameter batang tetapi tidak berpengaruh terhadap panjang cabang primer.

2. Pemberian pupuk NPK Phonska dengan dosis $500 \mathrm{~g} /$ tanaman memberikan pertumbuhan tanaman kakao terutama tinggi tanaman dan diameter batang yang terbaik.

\section{UCAPAN TERIMA KASIH}

Terima kasih kepada Universitas Widya Gama Mahakam, Samarinda yang telah membiayai penelitian ini melalui DIPA UWGM.

http://perkebunan.kaltimprov.go.id/conte nt.php?kebun $=$ berita\&code $=2 \&$ view $=54$ $\underline{3}$

Disbun Kaltim, 2013. Komoditi Kakao. http://disbun.kaltimprov.go.id/statis-36komoditi-kakao.html

Gardner, F. P., R. B. Pearce dan R. L. Mitcell. 1991. Fisiologi Tanaman Budidaya. Terjemahan Herawati Susilo. UI Press. Jakarta. 
Harjadi, S.S. 2002. Pengantar Agronomi. PT Gramedia Pustaka Utama. Jakarta.

Herman. 2000. Peranan dan prospek pengembangan komoditas kakao dalam perekonomian regional Sulawesi Selatan Warta Pusat Penelitian Kopi dan Kakao Indonesia, 16 (1) : 21 - 31.

Lingga, P. 2007. Petunjuk Penggunaan Pupuk. Penebar Swadaya. Jakarta.

Salisbury, F. B. dan C. W. Ross. 1997. Fisiologi Tumbuhan. Terjemahan Dian
Rukmana dan Sumaryono. ITB. Bandung.

Teja Primawati Utami. 2014. Peningkatan Daya Saing Kakao Nasional Melalui Kebijakan Hilirisasi. Pusat Pendidikan dan Pelatihan - Kementerian Perdagangan.

http://www.kemendag.go.id/pusdiklat/ne ws/wawasan/36

Tisdale, S. I., W. I. Nelson and J. D. Beaton. 2003. Soil Fertility and Fertilizers, Fourth Ed. Mac Millan Pub. Co. New York. 